\title{
Journal of Economics
}

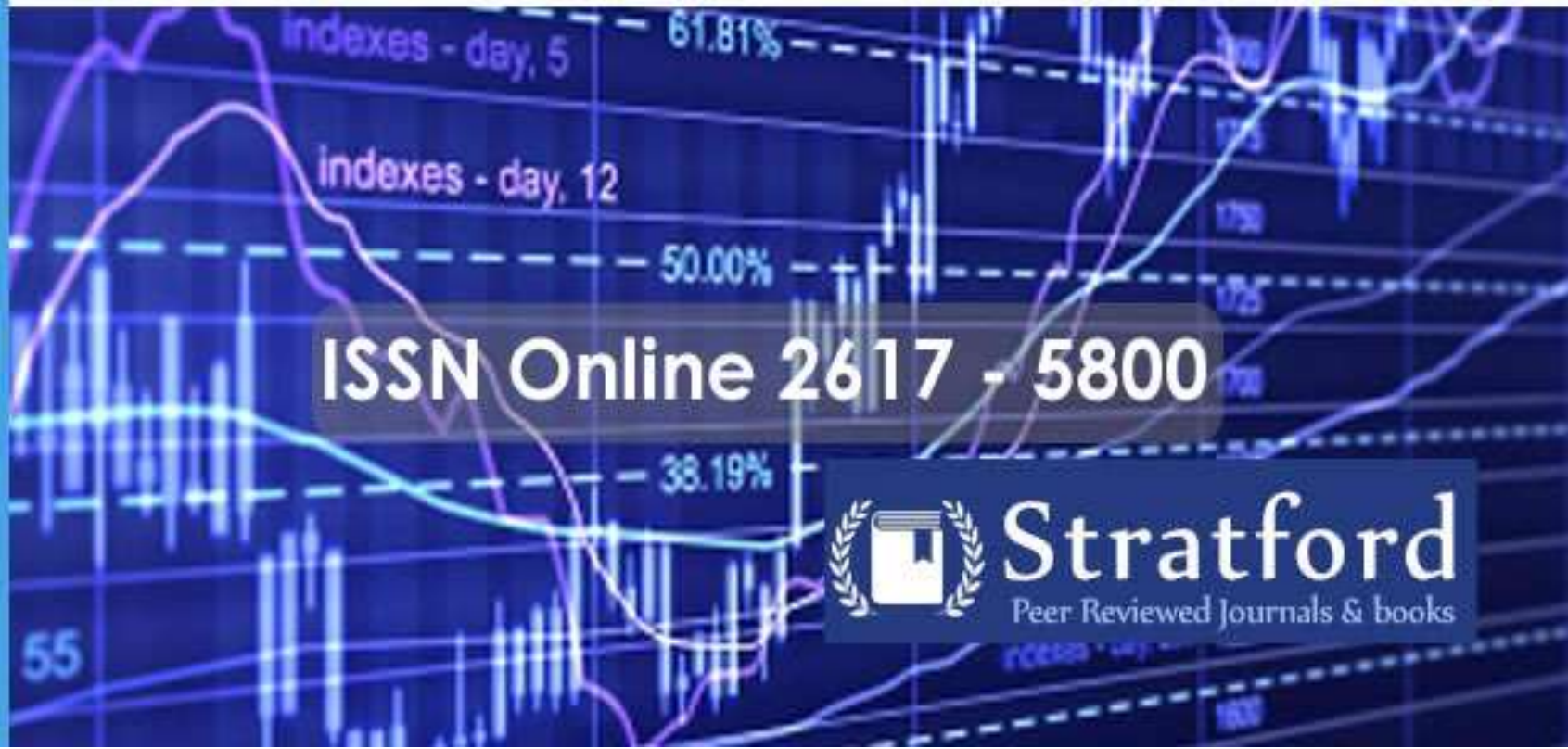

Effects of Financial Inclusion and Awareness Creation on Women Empowerment in Kalawa Ward, Makueni County-Kenya

Janet Mutua \& Nyaga G. Juster

ISSN: 2617-5800 


\title{
Effects of Financial Inclusion and Awareness Creation on Women Empowerment in Kalawa Ward, Makueni County- Kenya
}

\author{
${ }^{* 1}$ Janet Mutua \& ${ }^{2}$ Nyaga G. Juster \\ ${ }^{1}$ Master of Arts in Development Studies, School of Management and Leadership, \\ Management University of Africa \\ ${ }^{2}$ Lecturer, School of Management and Leadership, Management University of Africa
}

*E-mail of Corresponding Author: janmutuas@gmail.com

How to cite this article: Mutua, J. \& Juster, N. G. (2021). Effects of Financial Inclusion and Awareness Creation on Women Empowerment in Kalawa Ward, Makueni County-Kenya. Journal of Economics, 5(1), 48-64. https://doi.org/10.53819/81018102t4021

\begin{abstract}
Despite the ever-increasing number of NGOs in Makueni County aimed at socio-economic empowerment of women, gender inequalities are persistent and poverty levels are high. This is evident by low participation of women in decision making process, control over ownership and access of resources and wealth, increased poverty levels, increased cases of gender-based violence. This has necessitated the need to establish the role of NGOs in women empowerment in Makueni County. The purpose of the study was to establish the role of NGOs in financial inclusion of women and the creation of awareness on property rights for women. The anchor theory for this study is the Women Empowerment Framework by Sara Longwe and the other theories used in the study include Kabeers 3-dimensional model; the public goods theory of financial inclusion. The study population was 60 women groups in Kalawa ward, Makueni County who have benefited from the NGOs programs. The total number of respondents were 1254 and a sample size of 294 was used. The findings revealed that financial inclusion and awareness creation on the right to own resources and property influence women empowerment. The focus group discussions highlighted that the NGOs are doing very little in regards to awareness creation on the right of ownership of resources and property. Women cited that discrimination, being left out of development agenda, illiteracy and patriarchal nature of the society as the major challenge. The study recommendations were that NGOs, National and County Governments should provide linkage to markets for the products from the income generating activities by women groups. Both Government and NGOs should develop frameworks to engage women in development agenda.
\end{abstract}

Keywords: Women Empowerment, Financial Inclusion, Awareness Creation, NGOs, Makueni County. 


\subsection{Introduction}

NGOs have been in the fore front in promotion of financial inclusion among women. Women have been for a long time disadvantaged compared to their male counterparts in financial inclusion. According to Bennis (2016), in many households, only the males have bank accounts and are able to access financial services and products due to the patriarchal nature of the society. NGOs have taken initiatives to bring women on board in the financial world through the following initiatives: educating both women and men the importance of having women gain financial literacy and access to financial services and products (Esther, 2012); introduction of table banking systems where women groups are able to pull their monies together through a saving scheme and borrow loans at an affordable interest rate (Hedayat, 2010); and introduction of micro finance institutions at the grassroots which serve the needs of the women and give loans and financial education to women. Some of these financial institutions started by NGOs include Kenya Women Finance Trust (KWFT), Financial Services for Agriculture. (Bakare, 2014).

Over the decades, women have been deprived of their right to own property. This is majorly propagated by the patriarchal order of the society and lack of knowledge on the part of the women. This has made women vulnerable to poverty, food insecurity and landlessness in case of bereavement by their husbands or fathers since they have no right over the land and property. Many women are not allowed to own land or any other property and all rights have been reserved to their male counter parts. NGOs have taken initiative to break this norm and give women their rightful share of land and property. NGOs have been educating women on their rights to own property. Particular in Kenya, FIDA-Kenya has been in the front line educating and creating awareness on the rights of women as stipulated in the Kenyan constitution of 2010 (FIDA, 2010). Other NGOs have also taken the initiative to educate both men and women concerning these rights and have helped women fight for their rights of land and property ownership. In Makueni County, Makueni Paralegal Community Association has taken this advocacy role for the past 8 years (Kithuka \& Okwema, 2020).

Half of the world's population are women, and it endures social, economic and political challenges. Globally, according to World Economic Forum (2014) the society and specifically women tend to lag behind in aspects of socio-economic empowerment. This is the reason why empowerment of women is part of the UN Sustainable Development Goals (SDGs). Lack of involvement of women in development process leads to challenges such as increased cases of food insecurity and high incidence of poverty (Morton, 2011). NGOs have initiated programs geared towards empowering women economically, socially and politically.

Despite the ever-increasing number of NGOs in Makueni County aimed at socio-economic empowerment of women, gender inequalities are persistent and poverty levels are high. According to Kenya Demographic and Health survey (KDHS, 2019)by Kenya National Bureau of Statistics (KNBS) the level of poverty in Makueni County is estimated to be $34.8 \%$. This is evident by low participation of women in decision making process, control over ownership and access of resources and wealth, increased poverty levels, increased cases of gender-based violence, few or no income generating activities, poor health and low literacy levels among women. There is therefore need to establish the role played by NGOs in promoting women empowerment and how this leads to reduction of the socio-economic vulnerability of women. According to a study by KNBS (2020), it showed that in Kenya less than a third of women are empowered. This makes $29 \%$ of the total women in Kenya. $40 \%$ of women in urban area are considered to be empowered 
while only $22 \%$ of women in rural Kenya are considered to be empowered. The study by Kithuka \& Okwema (2020), which was carried in Makueni on women empowerment was to establish the effect of International Non-Governmental Organizations development programme on the socioeconomic empowerment in Makueni County. The study focused on role of International NGOs in socio-economic empowerment of women. There is no study to establish the role of NGOs on women empowerment in Makueni County and it is to this effect that this study is carried out to establish the role of Non-Governmental Organization in women empowerment in Makueni County.

The study objective was to establish the effects of financial inclusion and awareness creation on women empowerment in Makueni County. The study findings will provide guidance and insight to public policy makers in both county governments, national government and development partners on the role of NGOs in women empowerment and this will help them formulate policies which support NGO activities and women empowerment programs. The research findings will help NGOs focus their energies and resources on women empowerment. The study will give policy makers an insight into the issues related to women empowerment programs by NGOs. The recommendations of this study can be used as strategic direction for solving problems around women empowerment. The research findings will form a basis for further studies on the role of NGOs on women empowerment. Researchers and scholars will benefit from the information and data gathered from the study and this will add to the existing knowledge in the role of NGOs in women empowerment. The findings will be used as empirical literature in future studies by scholars. NGOs and women groups will use the study finding as basis for policy development. The study findings are expected to benefit the NGOs in their women empowerment endeavors. The NGOs will benefit by assessing, evaluating, and reviewing their practices and approaches as tools of effectiveness and efficiency the journey of women empowerment. The study findings will also shed light to the NGOs and women groups on what strategies to adopt for better outcome of their programmes and projects.

\subsection{Literature Review}

\subsection{Theoretical review}

\section{Women Empowerment Framework}

Women empowerment framework was advanced by Sara Longwe in the year 1995. In this framework Sara Longwe argues that mot development literature has focused on how equality between men and women has been achieved in conventional sectors in the economy. This has been done at the expense of equality of women in the process of development. In her framework, development entails enabling people to transform their lives and be delivered from poverty. Her argument is that poverty does not arise from lack of productivity but is rather caused by exploitation and discrimination. Longwes framework is based on five levels of equality. The extent to which these are present in any sphere of socio economic life determines the level of women empowerment. These five levels of empowerment include: welfare, access, Conscientization, mobilization and control. (Longwe, 2002).

Welfare is the lowest level at which a development initiative will use to close gender gap. Welfare in this case means improvement in the socio-economic conditions such as income, housing and nutrition. This is a zero level of empowerment since women are only recipients of these benefits and they are not producing or acquiring them by themselves. Access is the first level of empowerments since women can now improve their own status relative to men on their own. This

\section{https://doi.org/10.53819/81018102t4021}


is possible due to increased access to the requisite resources. For instance women in agriculture increase their productivity and welfare due to availability of water for irrigation, land, market for their produce and improved.

Conscientization is defined as the process through which women understand that their lack of status and welfare comparative to men is not due to their absence of ability and effort. It is realizing that women lack access to resources because of discrimination and prioritization of men in access to resources. Conscientization is therefore concerned with the urge to remove one or more of these discriminatory activities that hinder women from accessing resources. This process is driven by the need of women to understand the root causes of their problems and identifying possible strategies for action.

Mobilization is the step where action takes place. The first step of this level is women coming together to recognize and analyze the problem. They identify the strategies that will help solve the discrimination and the collective action to get rid of the practices. Communication at this stage does not necessarily concern the mobilization group but it connects with women movement, learning from success of other strategies by women in other strategies by women in other places and linking up with wider struggle for women rights. Leadership here involves taking the fore front in the mobilization process, providing space for organization and redirecting existing women organizations.

Control level is achieved when women have acted to ensure gender equity in decision making on access to resources so that they are in direct control in their access to resources. Women take what is rightly theirs and do not sit waiting to be given resources at the will of men. Information and communication play the role of spreading the development of successful strategies. These levels in the framework are not linear but their relationship is a cycle such that increased control leads to better access of resources which therefore leads to improved welfare and socio economic status. This framework best suits the study since it seeks to address the access and control of resources which is a factor affecting women empowerment. (Kibe, 2014).

\section{Public Goods Theory of Financial Inclusion}

This theory was developed by Paul Samuelson in 1950s. This theory argues that the delivery of formal financial services to the entire population and ensuring unrestricted access to finance be treated as a public good. As a result, individuals cannot be excluded or denied access to financial services and products. All members of the population will enjoy these financial services without paying for them and the access to the services by one is independent of access by others. (Ozili 2020).

Under this theory, every member of the population is a beneficiary and no single member is left out. Any individual or business that operates a bank account can access debit cards freely and can use the Automated Teller Machines without being charged transaction cost. The suppliers of the financial services bear the sunk cost of offering the services. (Hedayat, 2010) Government may offer subsidies to help the suppliers curb the cost problems emerging from offering free financial services. Government can also deposit lump sum cash into the accounts of all members and make owning formal account the only requirement to access the free lump sum deposit. This will enable the individuals who cannot pay their debts and meet their basic needs to stand a chance of being economically empowered. 
The theory has the following advantages: firstly, everyone benefits from the financial inclusion regardless of the social status, income level and demographic differences. This means both the poor, rich, men and women will enjoy the benefits of financial inclusion. The second advantage is that it will require public funding rather than private funding and this gives the government an opportunity to take responsibility in promoting financial inclusion. (Bakare, 2014)

The relevance of this theory in this study is it does not recognize the private sector agents and promoters of financial inclusion. The findings in this study will go a long way to review this theory. Either to affirm the theory or revise it to give the role of the private sector and NGOs in financial inclusion.

\subsection{Empirical review}

\subsubsection{Financial Inclusion and Women Empowerment}

A study conducted by Musingila (2011) on "Effects of Micro credit Finances on Women Empowerment in Mwingi North Subcounty, Kitui County" showed that women have limited access to financial facilities such as loans and credit facilities due to their lack of collateral. In most Kenyan communities, cultural factors hinder women from owning land and other assets which could be used as collateral for loans. Banking institutions have reservations giving loans without collateral.

A study by Robison (2013) on "Savings Constraints and Microenterprise Development" showed that financial inclusion can be transformative for women and enable them to manage risks better, have smooth consumption patterns even during economic shocks and enable them to fund household financial expenditures without depending on their male counterparts. (Robinson, 2013). Since women experience poverty in larger scale compared to males, giving women the right financial tools such as saving and borrowing money, making and receiving payments and managing risk is a key component of women empowerment. (Holloway, Rouse, \& Niazi, 2017)

A study done by ILO (2011) on "factors that affect the women entrepreneurs in Kenya" showed that twenty percent of women in developing countries are less likely to have an account in a financial institution and only $17 \%$ are likely to have borrowed from the financial institutions formally. If when have access to loan facilities they lack access to other forms of financial inclusion such as savings, digital payments and insurance services. The requirements to have a male family member permission to open account restrict women from having accounts. Most women also lack financial education which limit the women from accessing and getting benefits from financial services. World Bank in partnership with other organizations has advanced financial inclusion for women (ILO, 2011).

A study by Holloway et.al (2017) on "Women's Economic Empowerment through Financial Inclusion" cited availability and accessibility of financial tools as being one of the major barriers to women empowerment. In the study the role of NGOs in small scale enterprises owned by women was studied and factors such as lack of seed capital, lack of awareness on existing credit facilities long procedures for application of loans and lack of security are a major barrier to financial inclusion of women. This has in a great way hindered women empowerment since women are marginalized and excluded in financial matters. (Holloway, Rouse, \& Niazi, 2017).

NGOS are providing financial literacy. This is essential in increasing financial literacy and helping women to achieve empowerment. Studies show that improving women access to financial services has proven to be essential factor in unlocking the potential of women to manage their own

$$
\text { https://doi.org/10.53819/81018102t4021 }
$$


resources and helps reduce the exposure of the rural women to poverty. Financial inclusions has improved women's growth, promoted sustainable and equitable growth which are essential ingredients of women empowerment. (Waruguru, 2011).

A study by Musingila (2011) on "Effects of Micro credit Finances on Women Empowerment in Mwingi North Subcounty, Kitui County" indicated that financial inclusion has led to women empowerment by improving women access to financial services by micro finance institutions. The microfinance institutions were offering training through networking and mentorship. This has led to improved financial skills to women and this has contributed to women being able to make financial decisions in their households since they have skills on budgeting and savings. The study concluded that women who participate in micro finance activities have improved social networks, increased skill acquisition and improved leadership qualifications leading to improved women empowerment in decision making. (Musingila, 2011).

\subsubsection{Awareness Creation in Ownership Right and Women Empowerment}

The rights to ownership and access to property among women is a crucial component of women empowerment. It gives them access to resources and better living standards. It is an important aspect for women and girls in family setting either by choice or circumstance.. There are a lot of issues regarding rights for women to own, access, use and manage land and property. The discriminatory practices that women and girls should ask for permission to use land and property from their male counterparts is retrogressive. The complex myriad of cultural, social and legal factors and obstacles hinder women from achieving equal rights to ownership of land and property with their male counterparts. (Brass, 2010)

A study by Esther (2012) on "Women Empowerment and Economic Development" indicated that most women lack awareness on their rights to own land and property and they rarely have the power to enforce these rights. . Other than lack of awareness of their rights to own property as women, most of the women are ignorant of the laws which provide guidance on matters related to purchase, acquisition and registration of land and property. In most cases when women are bereaved, they do not know the procedure of seeking legal redress concerning succession matters and this makes them vulnerable and most people take advantage of this to deprive them their right of ownership. (Esther, 2012)

A report done by FIDA in 2010 on "Every mile counts. Building a legacy of women rights protection in Kenya. Annual report" shows that most laws cannot be easily understood by women since they are drafted in technical terms. Given the high levels of illiteracy among women, it discourages women from actively participating in the processes of acquiring, selling or leasing out property. This leaves the responsibility fully on their male counterparts who end up registering the property under their names hence disadvantaging the women. Most rural women due to the low illiteracy levels do not have access to the new constitution which guarantees them of their rights to land and property. This therefore hinders women from effectively claiming their land and property rights when need arises. (FIDA, 2010). Due to the identified legal, cultural and social obstacles, the rights to property rights for women are continually abused. This leads to the impoverishment of women.

A study by Akinola \& Adeoye (2018) on "Women, Culture and Africa's Land Reform Agenda", Kenyan women rights to land and property have continued to lag behind despite the existence of a progressive legal frameworks. Customary law governs $65 \%$ of the property and land in Kenya and it often disadvantages women in their rights to own property and land. Rights of women not

\section{https://doi.org/10.53819/81018102t4021}


living on the land governed by the custom law are limited by the patriarchal nature of Kenyan society. (Akinola \& Adeoye, 2018)

NGO's being an important player in development process and in the forefront of the campaign for women empowerment and rights of women, many NGOs have gone ahead to fill the gap through capacity building initiatives. NGOs have conducted campaigns on awareness of women rights to own land and property and to rally support. This is very important even in countries where there is formal legislations in place to protect the rights of women. Lack of knowledge on legal protection is a barrier to women claiming their rights and the existing socio-economic norms hinder the attainment of human rights on land and property.

The UN women increased the knowledge and awareness of approximately 15,000 women who are affected or infected with HIV. This was done in bid to overcome the barriers on the right of women over land and property. The increased awareness together with availability and accessibility of legal aid has led to increase in the ability of women to report to property related and inheritance violation and to seek legal redress. Action Aid has made efforts to help widows to learn and claim their rights. (Women, 2018).

A study conducted by Eunice Keli Wambua (2013) on the "Role of Women Organizations in Empowering Women in Mwingi District" indicated that most women are not aware of their rights to ownership of assets and land. The patriarchal nature of the society has the land under ownership of male. $85 \%$ of the women respondents indicated that the land they use is under their husbands or the male counterparts in the family. They are not aware of their right to own matrimonial property and this deprives them of ownership and access to the land and property to use it for their social economic empowerment.

A study by Elishiba Kimani (2016) on "Perception of Youth on Women Right to Ownership and Control of Matrimonial Property" showed that culture, family economic status and family are determinants of the rights to women having access to land and property. The study showed that despite youth who were respondents of the study acknowledging the rights of women in property ownership as enshrined in the Kenyan constitution 2010, they still hold to the belief that women should not own property. This retrogressive culture has contributed to the declining socioeconomic empowerment of women. (Kimani, 2016). 


\subsection{Conceptual Framework}

Independent Variables

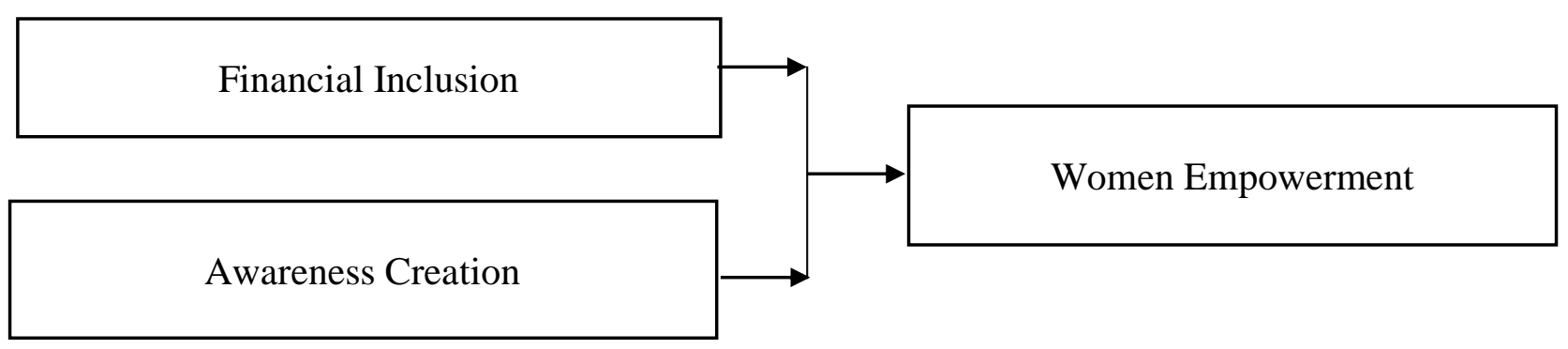

Dependent Variable

\section{Figure 1: Conceptual Framework.}

\section{Source: Author (2021)}

\subsection{Methodology}

The study adopted correlational research design. Correlational research involves measuring two or more variables and assessing the relationship between them, without manipulating the independent variable. Correlational research involves observing two or more variables to establish statistically corresponding relationship between them. The study population for this research was the projects in Kalawa ward, Makueni County done by NGOs. The key respondents were women groups which have benefited from these projects. The reason for selecting ward is because it houses most NGOs in the county hence it was easy to get respondents who have interacted with the NGOs and benefited from NGO programs and projects. The target population is 60 registered women groups. The respondents were be 1254 members of those women groups

The study sample was 294. This is the acceptable sample size (Taherdoost, 2016) recommends that any large sample should form at least $10 \%$ of the target population. The research used stratified random sampling technique which is defined as a method where the population under study is divided into sub groups (strata) and from each stratum a random sample is taken. This method is used in situations where there is a great variation within the population. The sample size for the study is calculated at $95 \%$ confidence level with a margin of error of $5 \%$.

This study used questionnaire for data collection. A questionnaire is a research instrument with a series of questions for purposes of getting information from respondents. (Blumberg, et.al, 2011). The questionnaire had closed and open-ended questions and a 5-point Likert scale. Due to the scatteredness of the sample across the ward, the questionnaires were distributed to women groups during their meetings and after they fill, the data collection clerks collected the form. Interviews were conducted for the focus group discussions where the women gave success stories of their interactions with the NGOs and highlight challenges and give possible solutions and suggestions on how better the NGOs can help them.

The analysis of the quantitative data was done through descriptive statistics, and the presentation was done through charts, tables and in prose. Qualitative data was coded into the different objectives and analyzed by content analysis. Content Analysis is a research tool that is used to

\section{https://doi.org/10.53819/81018102t4021}


determine, quantify and analyze the presence of certain concepts, themes and phrases within some qualitative data. (Wilson, 2010). The Statistical Package for Social Sciences (SPSS) software and Microsoft Excel were used in data analysis.To test variable relationships inferential statistics was used and regression analysis and correlation analysis were to determine relationship between the variables. F-test ANOVA and t-test was used for these tests. The Pearson correlation analysis showed how independent variables influence the dependent variable.

The regression model is as follows: $\boldsymbol{Y}_{\boldsymbol{0}}=\boldsymbol{\beta}_{1}+\boldsymbol{\beta}_{1} \boldsymbol{X}_{1}+\boldsymbol{\beta}_{2} \boldsymbol{X}_{2}+\boldsymbol{e}$

Where;

$\mathrm{Y}_{0}=$ women empowerment;

$\beta_{0}=$ constant;

$\beta 1, \beta 2=$ Coefficients of the study variables

$\mathrm{X}_{1}=$ Financial inclusion

$\mathrm{X}_{2}=$ Awareness creation

$\mathrm{e}=$ Error term

\subsection{Findings and Discussion}

\section{Financial Inclusion and Women Empowerment}

Majority of the respondents (54.04\%) agreed that financial inclusion had great influence in women empowerment. $30.38 \%$ strongly agreed that financial inclusion had influence of women empowerment. 8.6\% were neutral on the role of financial inclusion on women empowerment. $6.04 \%$ disagreed that financial inclusion influences women empowerment while $0.94 \%$ strongly disagreed. $87.7 \%$ of the respondents agreed that NGOs provide financial education to women while $4.3 \%$ were neutral and $8.1 \%$ disagreed. $82.2 \%$ of the respondents agreed that NGOs provide financial awareness programs to encourage women to make better informed decisions. $90.6 \%$ agreed that NGOs help form small units like self-help groups and help these groups in accessing savings and credit facilities. $75.3 \%$ of the respondents agreed that NGOs provide a link to enable women access savings and credit facilities. $86.4 \%$ of the respondents agreed that NGOs have helped women access financial service and products which match their needs.

\section{Regression Analysis of the Influence of Financial Inclusion on Women Empowerment}

The first objective of the study was aimed at establishing the influence of financial inclusion on women empowerment. The model summary in Table 1 demonstrates the coefficient of determination as indicated by Adjusted R square to be 0.347 implying that $34.7 \%$ of women empowerment is explained by Financial Inclusion. 
Table 1: Model Summary for Financial Inclusion and Women Empowerment

\begin{tabular}{llllll}
\hline Model & R & R Square & Adjusted R Square & $\begin{array}{l}\text { Std. Error of the } \\
\text { Estimate }\end{array}$ & \\
\hline 1 & $.591 \mathrm{a}$ & .350 & .347 & .49176 & \\
\hline
\end{tabular}

a. Predictors: (Constant), Financial inclusion

\section{Source: Author (2021)}

In Table 2 the ANOVA was used to show the overall model significance. Since the p-value is less than 0.05 , then $\mathrm{X}_{1}$ had a significant explanatory power on $\mathrm{Y}(\mathrm{F}=125.343$ and $\mathrm{p}$-value $<0.05)$.

Table 2: ANOVA for Financial Inclusion and Women Empowerment

\begin{tabular}{lllllll}
\hline Model & & Sum of Squares df & Mean Square & F & Sig. \\
\hline 1 & Regression & 30.312 & 1 & 30.312 & 125.343 & $.000^{\mathrm{b}}$ \\
& Residual & 56.346 & 233 & .242 & & \\
& Total & 86.658 & 234 & & & \\
\hline
\end{tabular}

a. Dependent Variable: Y, b. Predictors: (Constant), Financial inclusion

Source: Author (2021)

From Table 2 regression equation can be written as:

$\mathrm{Y}=1.721+0.611 \mathrm{X}_{1}$

Where $\mathrm{X}_{1}=$ Financial inclusion and $\mathrm{Y}=$ women empowerment.

The regression equation above shows that when financial inclusion is held constant at zero, women empowerment would be 1.721 units.There is an influence of financial inclusion on women empowerment. A unit increase in financial inclusion increases women empowerment by 0.611 Units. Since the p-value is less than 0.05 we conclude that there is a significant influence of financial inclusion on women empowerment. This is in line with a study done by Shivangi Bhatia (2019) on Empowering Women through Financial Inclusion: A Study of Urban Slum in India. The findings indicated that there is significant influence of financial inclusion levels on economic, social and political empowerment of women in slums. The study also showed that even the less educated women in the slums had joined banking systems and were aware of financial inclusion schemes. Both NGOs and Self-help Group in India are playing a vital role in creating awareness on financial inclusion. The results of the Focus group discussion of the study conducted in kalawa ward shows that NGOs are encouraging table banking among women and are encouraging them to open bank accounts for their savings and transactions. The NGOs also offer financial education in matters regarding books of accounts and financial decisions. The NGOs are educating men on the importance of women owning bank accounts. The only challenge is the accessibility of the bank facilities. The area is remote and the bank agents most of the times do not have float for deposits or the network fails. 
Table 3: Regression Coefficients between Financial Inclusion and Women Empowerment

\begin{tabular}{lllllll}
\hline \multicolumn{5}{c}{} & \multicolumn{5}{c}{ Unstandardized Coefficients } & $\begin{array}{l}\text { Standardized } \\
\text { Coefficients }\end{array}$ & \\
Model & & B & Std. Error & Beta & t & Sig. \\
\hline & (Constant) & 1.721 & .224 & & 7.670 & .000 \\
& $\mathrm{X}_{1}$ & .611 & .055 & .591 & 11.196 & .000 \\
\hline
\end{tabular}

a. Dependent Variable: Y; Financial inclusion

Source: Author (2021)

\section{Awareness Creation}

Majority of the respondents $(67.40 \%)$ disagreed on the role of awareness creation on the right of property and resource ownership in women empowerment. $10.96 \%$ were neutral on the influence of awareness creation on the right of property and resource ownership in women empowerment. $10.10 \%$ strongly disagreed, $7.98 \%$ agreed while $3.5 \%$ strongly agreed on the influence of awareness creation on the right of property and resource ownership on women empowerment. $80.9 \%$ of the disagreed that NGOs have ensured better access to information regarding rights to ownership of land and property, $11.1 \%$ of the respondents agreed while $8.1 \%$ were neutral $81.2 \%$ of the respondents disagreed that NGOs support initiatives of women that aim at addressing land and property issues concerning women, $11 \%$ of the respondents agreed while $7.7 \%$ were neutral. $80.4 \%$ of the respondents disagreed that NGOs strengthen women groups support models on rights to ownership of land and property, $11.9 \%$ agreed while $7.7 \%$ were neutral. $67.7 \%$ of the respondents disagreed that NGOs provide legal information and capacity development on land rights, only $11.9 \%$ agreed while $20.4 \%$ of the respondents were neutral. The study findings therefore imply that awareness creation on rights of property and resource ownership influences women empowerment in Kalawa ward.

\section{Regression Analysis of the Influence of Awareness Creation on Women Empowerment}

The second objective of the study was designed to establish the influence of awareness creation on the right of property and resource on women empowerment. The literature that was reviewed in this study as well as theoretical reasoning associated awareness creation on the right of property and resource with women empowerment.

The model summary in table 4 demonstrates the coefficient of determination as indicated by Adjusted R square to be 0.020 implying that $2 \%$ of women empowerment is explained by awareness creation on the right of property and resources. 
Stratford Peer Reviewed Journals and Book Publishing

Journal of Economics

Volume 5||Issue 1||Page 48-64||October||2021|

Email: info@stratfordjournals.org ISSN: 2617-5800

Table 4: Model Summary of Awareness Creation on Women Empowerment

\begin{tabular}{llllll}
\hline Model & R & R Square & Adjusted R Square & $\begin{array}{l}\text { Std. Error of the } \\
\text { Estimate }\end{array}$ & \\
\hline 1 & $.154 \mathrm{a}$ & .024 & .020 & .60254 & \\
\hline
\end{tabular}

Predictors: (Constant), awareness creation

Source: Author (2021)

In table 5 the ANOVA was used to show the overall model significance. Since the p-value is less than 0.05 , then of awareness creation on the right of property and resource had a significant explanatory power on women empowerment. ( $\mathrm{F}=5.693$ and $\mathrm{p}$-value $<0.05)$.

Table 5: ANOVA Table for Awareness Creation on Women Empowerment

\begin{tabular}{lllllll}
\hline Model & & \multicolumn{2}{l}{ Sum of Squares df } & Mean Square & F & Sig. \\
\hline 1 & Regression & 2.067 & 1 & 2.067 & 5.693 & $.018^{\mathrm{b}}$ \\
& Residual & 84.591 & 233 & .363 & & \\
& Total & 86.658 & 234 & & & \\
\hline
\end{tabular}

a. Dependent Variable: Y, b. Predictors: (Constant), Awareness creation

Source: Author (2021)

From table 6 regression equation can be written as:

$\mathrm{Y}=4.485-0.122 \mathrm{X}_{2}$

Where $\mathrm{X}_{2}$ is awareness creation on the right of property and $\mathrm{Y}$ is women empowerment.

The regression equation above shows that when of awareness creation on the right of property and resource is held constant at zero, women empowerment would be 4.485 units. There is an influence of awareness creation on the right of property and resource on women empowerment. A unit increase in of awareness creation on the right of property and resource decreases women empowerment by 0.122 Units. Since the p-value is less than 0.05 we conclude that there is a negative significant influence of awareness creation on the right of property and resource on women empowerment. This is in line with a study conducted on "Bariers facing women in access, control and ownership of land" done by Mary Chepkemoi. It shows that $56 \%$ of the respondents felt that training on women rights to ownership of property would contribute to women ownership of land. The study agrees with Ireri (2016) recommendation that women should be educated on their rights to own property and resources. A study conducted by Eunice Keli on "the Role of women organizations in empowering women; a case study of Mwingi district". The findings of the study showed that $66 \%$ of the women respondents are aware of their rights to own property. And only 54\% do not own assets and property. The study showed that majority of the assets are owned by the male counterparts. A study done in Nepal on "Barriers to women ownership of land and property" by International Organization to Migration in 2011 showed that only $10.9 \%$ of women have land and property in their names. This however does not translate to control of the property. The control is solely under men and they are the main decision makers in matters regards to use or disposing the property. The focus group discussion in Kalawa showed that most of the women do not own resources and property but their husbands allow them to use them for

\section{https://doi.org/10.53819/81018102t4021}


productive activities. NGOs have done some sensitization on importance of having women own property but the cultural norms are hindering the smooth transition. Men still believe that women owning property will lead to insubordination and lack of respect.

Table 6: Regression Coefficients on Awareness Creation and Women Empowerment

\begin{tabular}{|c|c|c|c|c|c|c|}
\hline \multirow{2}{*}{\multicolumn{2}{|c|}{ Model }} & \multicolumn{2}{|c|}{ Unstandardized Coefficients } & \multirow{2}{*}{$\begin{array}{l}\text { Standardized } \\
\text { Coefficients } \\
\text { Beta }\end{array}$} & \multirow[b]{2}{*}{$\mathbf{t}$} & \multirow[b]{2}{*}{ Sig. } \\
\hline & & B & Std. Error & & & \\
\hline 1 & (Constant) & 4.485 & .123 & & 36.539 & .000 \\
\hline & $\mathrm{X} 2$ & -.122 & .051 & -.154 & -2.386 & .018 \\
\hline
\end{tabular}

a. Dependent Variable: Y

Source: Author (2021)

Overall multiple regression model

Table 7: Table of coefficients

\begin{tabular}{|c|c|c|c|c|c|c|}
\hline \multirow[b]{2}{*}{ Model } & & \multicolumn{2}{|c|}{ Unstandardized Coefficients } & \multicolumn{2}{|c|}{$\begin{array}{l}\text { Standardized } \\
\text { Coefficients }\end{array}$} & \multirow[b]{2}{*}{ Sig. } \\
\hline & & $\bar{B}$ & Std. Error & Beta & $\mathbf{t}$ & \\
\hline & (Constant) & 1.848 & .281 & & 6.588 & .000 \\
\hline & $\mathrm{X}_{1}$ & .565 & .062 & .547 & 9.083 & .000 \\
\hline 1 & $\mathrm{X}_{2}$ & .043 & .050 & .055 & .862 & .390 \\
\hline
\end{tabular}

a. Dependent Variable: $\mathrm{Y}$

Source: Author (2021)

The results in table 7 show that there was a significant influence of financial inclusion on women empowerment $\left(\beta_{1}=.565\right.$; P-value $\left.<0.05\right)$. This suggests that a unit change in financial inclusion increases women empowerment by 0.565 units. Additionally, there is a significant influence of awareness creation on rights to ownership of property and resources on women empowerment ( $\beta_{1}$ $=0.043 ; \mathrm{P}$-value $<0.05$ ). This implies that a unit change in awareness creation on rights to ownership of property and resources increases women empowerment by 0.043 units.

\subsection{Conclusions and Recommendations}

The research concluded that financial inclusion influences women empowerment. When women are able to access savings and credit facilities, they can borrow to invest and use their savings in doing businesses or investing in assets which generate income. This gives women confidence in participating in household decisions about finances. The ability of women being involved in major decision making is a component of women empowerment. The financial inclusion gives women capacity to meet their basic needs thorough savings and borrowing. This has enabled women pay fees for their girls who in most cases are not educated in favor of the boy child. This contributes to women empowerment since the girl child is able to access education. Participation in the table banking helps women learn book keeping and financial management which makes them make better financial decisions and empower the women financially and economically. 
The research concluded that awareness creation in right to own resources and property influences women empowerment. The ownership of property and resources makes women access financial services since they can use title deeds and assets to acquire loans from financial institutions and banks. The ownership of land and assets will enable women to make production decisions such as which parcel of land will be used for farming or livestock rearing. Ownership of property will allow women sell land and use the proceedings to invest or educate their children. With women owning property, they are able to survive the discrimination from their family members against owning their matrimony property once the husband dies. This will cushion them against delving into poverty.

Both National and County Government to provide safe spaces for women to participate in development agenda. Develop guidelines on the engagement of women in development agenda. National and County government to provide policy guidance on awareness creation on rights to own property and production resources by women. Develop policy which safeguards the constitutional right to property and resource ownership by women. Develop a framework with which women complaints against discrimination on matters of property ownership can be anchored on.

NGOs, National and County Governments to provide linkage to markets for the products from the income generating activities by women groups. Develop marketing strategy for the products and market them. Introduce value chain addition for the agricultural products to minimize post-harvest losses. Sensitize men on the importance of women participating in income generating activities, land and property ownership and resource accessibility. Hold sensitization forums and bring on board constitutional experts and development practitioners to talk to the men.

Further studies to be done in other wards and counties to confirm the findings. Studies to be done on the role of NGOs in women empowerment with the target population being the NGOs. This will help establish the extent to which NGOs have had efforts in the process of women empowerment. Studies to be carried out on factors hindering women empowerment in Makueni especially kalawa ward, Kitise/ Kithuki ward, Mavindini ward and Nguu Masumba ward which are the poorest wards in the county yet they have majority of NGOs working in the areas. This will help establish why the areas continue being impoverished despite the many NGOs driving development agenda. The recommendations will help in reengineering the strategies and approaches employed by the NGOs to achieve better results. 


\section{REFERENCES}

Akinola, \& Adeoye, O. (2018). Women, Culture and Africa's Land Reform Agenda. Pretoria: University of Zululand Richards Bay, South Africa.

Bakare, O. (2014). Impact of civil society organization on sustainable development in developing countries. African Research Review. . International multi discplinary Journal, 205-227.

Bennis, H. (2016). The role of NGO in women empowernmet . Tunisia.

Blumberg, B., Cooper, D. R., \& Schindler, P. S. (2011). Business Research Methods. Boston.: McGraw Hill,.

Brass, J. N. (2010). Surrogates for Government, NGOs and the state in Kenya. Unpublished Dissertation . Berkeley C.A: University of California.

Esther, D. (2012). women empowerment and economic development . journal of economic literature, 1051-79.

FIDA. (2010). Every mile counts. Building a legacy of women rights protection in Kenya. Annual report. . Nairobi: FIDA Kenya.

Hedayat, N. (2010). Role of NGO in promoting Empowerment for sustainable community development. Dehli India.

Holloway, K., Rouse, R., \& Niazi, Z. (2017). Women's Economic Empowerment Through Financial Inclusion. Chicago: Innovations for Poverty Action (IPA).

Ile, U. (2016). perspective on self reliance and sustainable development in Nigeria. Nigeria.

ILO. (2011). Factors affecting Women Entrepreneurs in Micro and Small Enterprises in Kenya. Geneva: International Labour Office .

Kabeer, N. (2005). Gender equality and Women Empowerment : a critical analysis of the third millenium development goals. London: Institute of Development Studies University of Suxxess.

KDHS. (2019). Kenya Demographic and Health Survey. Nairobi: KNBS. 
Kibe, N. (2014). Government And Program Implementation Bodies Policies On Performance Of Women Empowerment Projects In Dagoretti Area, Nairobi County, Kenya. Nairobi: Kenyatta University Press.

Kimani, E. (2016). Perception of youth on women rights to ownership snd control of matrimonial propety. American Journal of Arts and Humanities, 12-24.

Kithuka, E., \& Okwema, P. (2020). Effect of International Non- Governmental Organizations Development Programmes on the Socio-Economic Empowerment of Women in Makueni County, Kenya. IOSR- Journal of Humanities and Social Sciences, 3-4.

KNBS. (2020). New Women's Empowerment Index for Kenyan Women and Girls. Nairobi: UN Women.

Little, G. (2015). Innovative grassroot NGOs and the complex process of women empowerment. An empirical investigation from Northern Tanzania. In J. L. M. Goldman, World Development (pp. 762-777). Dodoma: Arusha University Press.

Longwe, S. H. (2002). Addressing Rural Gender Issues: A Framework for Leadership and Mobilisation. Paper presented at the III World Congress for Rural Women, (pp. 6-8). Madrid.

Morton, B. (2011). AN Overwiew of International NGOs in Development Cooperation. Nairobi: UNDP.

Musingila, A. (2011). Effects of Micro Credit Facilities to women empowerment in Mwingi District. Nairobi: University of Nairobi.

Robinson, D. (2013). Savings Constraints and Microenterprise Development. Savings Constraints and Microenterprise Development, 163-192.

Taherdoost, H. (2016). Sampling Methods in Research Methodology; How to Choose a Sampling Technique for Research. SSRN Electronic Journal , 5(2):18-27.

UN. (2013). Realizing women rights to land and other productive resources. New York and Geneva : UN.

W., K. (2014). women urged to adopt table banking. The Star. 
Waruguru, M. M. (2011). The role of informal finance in empowering women at household level in Sagana Division, Kirinyanga County. Kenya: University of Nairobi.

Wilson, J. (2010). Essentials of Business Research. New Delhi: SAGE Publications India Pvt Ltd.

Women, U. (2018, 11 30). United Nations Women Africa Empoer women and gilrs in rural areas to achieve the SDGs and Africa Agenda 2063. Retrieved from united Nations Women Africa Website: www.UNwomen.com 